\title{
Evidence of Fire Use by Homo erectus pekinensis: An XRD Study of Archaeological Bones From Zhoukoudian Locality 1, China
}

\author{
Chao Huang ${ }^{1,2,3}$, Jingshu $\mathrm{Li}^{1,2}$ and Xing Gao ${ }^{1,2,3 *}$ \\ ${ }^{1}$ Key Laboratory of Vertebrate Evolution and Human Origins, Institute of Vertebrate Paleontology and Paleoanthropology, Chinese \\ Academy of Sciences, Beijing, China, ${ }^{2}$ CAS Center for Excellence in Life and Paleoenvironment, Beijing, China, ${ }^{3}$ College of Earth \\ and Planetary Sciences, University of Chinese Academy of Sciences, Beijing, China
}

\section{OPEN ACCESS}

Edited by:

Dongju Zhang,

Lanzhou University, China

Reviewed by:

Robin Dennell,

the University of Sheffield,

United Kingdom

Chunxue Wang

Jilin University, China

${ }^{*}$ Correspondence:

Xing Gao

gaoxing@ivpp.ac.cn

Specialty section:

This article was submitted to

Paleontology,

a section of the journal

Frontiers in Earth Science

Received: 08 November 2021 Accepted: 23 December 2021 Published: 19 January 2022

Citation:

Huang C, Li J and Gao X (2022) Evidence of Fire Use by Homo erectus pekinensis: An XRD Study of Archaeological Bones From

Zhoukoudian Locality 1, China. Front. Earth Sci. 9:811319. doi: 10.3389/feart.2021.811319
Zhoukoudian Locality 1 is well known both for the discovery of Homo erectus fossils and for the presence of early evidence of controlled use of fire by hominins; However, the nature of the latter had been seriously questioned since mid-1980s. To obtain substantial evidence of fire use by hominins, we combine macroscopic observations and XRD analysis on 23 fossil bones from new excavations in Layers 4 and 5. The crystalline index shows that at least 15 fossil bones were heated above $600^{\circ} \mathrm{C}$, and this is partly consistent with macroscopic observations. The high intensity burning of bones may indicate strong evidence of hominin-controlled use of fire at Layer 4. Future work should focus on archaeological materials from lower layers to improve our understanding of the nature of colored bones and gain more solid evidence of fire use by early humans at Zhoukoudian.

Keywords: Pleistocene, Zhoukoudian locality 1, Homo erectus pekinensis, burned bone, crystalline, use of fire, zooarchaeology

\section{INTRODUCTION}

Zhoukoudian Locality 1, situated about $50 \mathrm{~km}$ southwest of Beijing, China, (Figure 1), has been well known since the 1920s for the discovery of a large number of Homo erectus pekinensis fossils and thousands of stone artifacts. In addition, some burned items were also uncovered from the site, such as charcoal, stones and bones and they were widely accepted as the oldest reliable evidence of hominin use and maintenance of fire in the world (Black, 1931; Pei, 1934). From 1980s to the beginning of this century, based on information derived from taphonomy, geochemistry and spatial analysis, scholars have begun to doubt the evidence of in situ burning at the site and further the notion that Homo erectus pekinensis had the ability to control fire (Binford et al., 1985; Binford et al., 1986; Weiner et al., 1998; Goldberg et al., 2001; Boaz et al., 2004). Researchers from China refuted these arguments from perspectives of elemental carbon concentration and taphonomic observations (Wu, 1999; Shen, 2004).

In a recent excavation campaign conducted at Zhoukoudian Locality 1 since 2009, burned sediments and roughly one hundred of burned bones have again been unearthed from the site (Gao et al., 2016; Gao et al., 2017). By analyzing soil samples sourced during the new excavations in Layer 4, Zhong et al. (2013) detected siliceous aggregates which provided compelling evidence of the in situ use of fire by hominins at the site. Zhang et al. (2014) analyzed the sediment from the same Layer by 


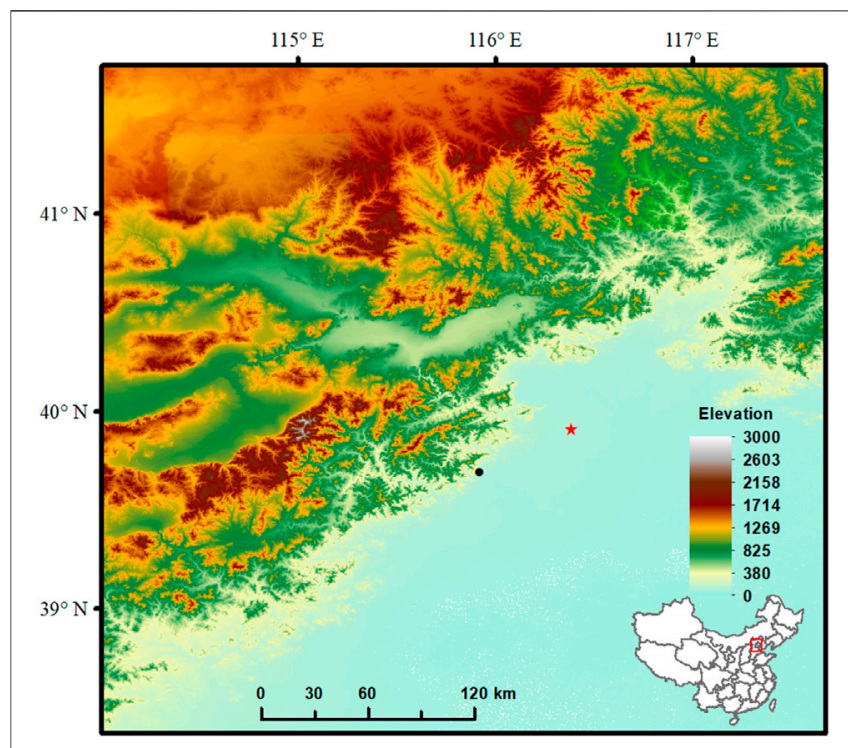

FIGURE 1 | The location of Zhoukoudian Loc.1.

examining its magnetic susceptibility, diffuse reflectance spectrum and color and presented further evidence of human controlled use of fire rather than a natural fire at the site.

However, it seems clear that these recent studies were focused essentially on sedimentary samples sourced from Layer 4, which represents in essence a single source of fire use at the site. In this study, we will pursue a different avenue and conduct an analysis of the newly excavated burned bones from the site.

In Paleolithic sites, burned bones are mostly used as an evidence of hominin use of fire (Black, 1931; Oakley, 1956; Brain \& Sillen, 1988; Brain, 1993; Sillen \& Hoering, 1993; Roebroeks \& Villa, 2011; Gao et al., 2017; Hlubik et al., 2017). The presence of burned bones in an archaeological site might indicate a series of human activities such as meat processing (Brain, 1993; Wrangham \& Conklin-Brittain, 2003), bone disposal (Yravedra \& Uzquiano, 2013), hearth making (Bennett, 1999) and fuel management (Théry-Parisot, 2002).

A common practice employed by taphonomists during the past decades to differentiate the burned and unburned bone and further to estimate the intensity of burning is actually based on the color and/or texture of the bones from the archaeological sites (Baby, 1954; Wells, 1960). However, it has become clear now that color is a poor criterion in recognizing burned bones and estimating the intensity of burning (Oakley, 1961; Herrmann, 1977; Brain \& Sillen, 1988; Brain, 1993; Sillen \& Hoering, 1993; Taylor et al., 1995; Shahack-Gross et al., 1997; Thompson, 2004; Squires et al., 2011).

There are numerous researches that focus on analyzing the processes undergone by bones and sediments in archaeological or paleontological sites. In many of those researches, it is common to find that thermal events affected both bones and sediments (Weiner et al., 1993; Person et al., 1995; Stiner et al., 1995; Schiegl et al., 1996; Stiner et al., 2001; Monge et al., 2014). However, the recognition of burned bones from archaeological sites is not straightforward. A dark color on the bones may indicate a result of burning, but it could be due to staining by iron oxides or/and manganese. This situation has led to a lot of experimental studies of identifying burned bones and the intensity of their burning (Shipman et al., 1984; Buikstra \& Swegle, 1989; Nicholson, 1993; Stiner et al., 1995; Schiegl et al., 1996; Bennet, 1999; Stiner et al., 2001; Lebon et al., 2008; Lebon et al., 2010; Reidsma et al., 2016; Schmahl et al., 2017; Greiner et al., 2019; Hoesel et al., 2019). These studies have concluded that thermal events could lead to a series of changes in color, texture, mineral phase, crystallinity, and modification of mechanical properties. In our study, we intend to combine XRD (X-Ray Diffraction) techniques and macroscopic observation to identify burned bones and estimate the intensity of their burning at Zhoukoudian Loc.1, and we hope this study will support evidence of hominin maintenance and use of fire at the site.

\section{MATERIALS AND METHODS}

From Layers 4 and 5, based on the state of preservation and thermal effects, we took a total of 23 samples of fossil bone. The fossils we used in this study were from the re-excavation of the Peking Man site at Zhoukoudian Locality 1.

The chronology of the use of fire by Homo erectus pekinensis was studied in 1991 using fission-track dating to find that the ash present at Locality 1 was likely deposited $299 \pm 55$ ka (Layer 4; Guo et al., 1991). Thermoluminescence dating was also applied at this site, generating an age of 292-312 ka for Layer 4 (Pei, 1985). Shen et al. (2001) using mass spectrometric U-series dating of intercalated calcite samples from the sediments at the site, proposed a date of $400 \pm 8 \mathrm{kyr}$ ago for an upper horizon of Layer $1 / 2$ and $\sim 500 \mathrm{kyr}$ ago for the upper part of Layer 5 . Thus, a range of 400-500 ka could be reasonably estimated for Layer 4, which was stratigraphically situated in-between these strata. It is notable that the dates for Layer 4 proposed by Guo et al. (1991), Pei, (1985) are far different from the estimates we obtained for the same layer by interpolating of the dating sets reported by Shen et al. (2001). Nonetheless, it has been argued that mass spectrometric U-series dating of pure calcite samples is a more reliable chronometer (Ludwig and Renne, 2000; Richards and Dorvale, 2003); this argument seems reinforced by an independent check conducted at Zhoukoudian recently (Shen et al., 2009). In this paper, we choose to use the older age for Layer 4 as indicated in the work of Shen et al. (2001).

\section{Macroscopic Observation}

We photographed all fossil bones and collected data on features including surface modifications. The bone surfaces were first examined by naked eye under strong incandescent light; potential marks of interest were then scrutinized using a $40 \times$ hand-lens and a Wild Heerbrugg microscope. Macroscopic characteristics (color and texture) of burned bones were identified following measures described by Stiner et al. (1995), Nicholson (1993), Buikstra and Swegle (1989).

Color is most commonly used to identify burned bone and the intensity of heat that the bone reached. The color code 
TABLE 1 | Burn color code and descriptions by criteria.

\begin{tabular}{|c|c|c|}
\hline Code & Color & Description \\
\hline 0 & Unburned white & $\begin{array}{l}\text { Not burned } \\
\text { Off-white/cream/tan }\end{array}$ \\
\hline 1 & Brown or red & $\begin{array}{l}\text { Slightly burned } \\
\text { Localized and }<50 \% \text { black }\end{array}$ \\
\hline 2 & Dark brown & $\begin{array}{l}\text { Lightly burned } \\
>50 \% \text { black }\end{array}$ \\
\hline 3 & Black & $\begin{array}{l}\text { Fully carbonized } \\
\text { Completely black }\end{array}$ \\
\hline 4 & Gray & $\begin{array}{l}\text { Localized }<50 \% \text { calcine } \\
\text { White appears but }<\text { black }\end{array}$ \\
\hline 5 & Light Gray & $\begin{array}{l}>50 \% \text { calcined } \\
\text { White > black }\end{array}$ \\
\hline 6 & White & $\begin{array}{l}\text { Fully calcined } \\
\text { Completely white }\end{array}$ \\
\hline
\end{tabular}

described in the Munsell soil color chart (Munsell Color Company, 1954) was used with a seven-grade scale (0-6) as described by Stiner et al. (1995), based on amount of carbonization and calcination and incorporating the colors described by Nicholson (1993). The revised criteria we used in recording color are listed in Table $\mathbf{1}$.

Texture changes were taken together with color to help corroborate the extent of burning. Overall texture of burned bones was recorded following Nicholson, (1993) four-stage description; a standard light microscope was sufficient for the texture observations. Table 2 shows the code we used in describing bone textures.

\section{XRD Analysis}

In early studies, many scholars mentioned that it could be determined whether skeletal remains had been burned, and the maximum temperature they reached, by matching their X-ray diffraction patterns (Shipman et al., 1984; Holden et al., 1995; Rogers and Daniels, 2002; Etok et al., 2007; Lebon et al., 2010; Greiner et al., 2019; Hoesel et al., 2019). All pointed out a phenomenon by which the XRD pattern of burned bone would become sharper when heated to $550^{\circ} \mathrm{C}$ or $600^{\circ} \mathrm{C}$ or above, although diagenesis and lowtemperature heating may cause similar phenomena in bone mineral change. In our previous study, we saw a similar phenomenon in three distinct types of experimental burned bone (Huang and Zhang, 2021).

To identify mineral phases and crystallinity, we ground all bone fossils to a fine powder using an agate mortar. It is noted that samples of two colors were taken from different parts in the cases of NO.12Z1-862 and NO.12Z1-2103 (Figure 2). The colors of powdered samples were recorded by reference to the Munsell soil color chart (Munsell Color Company, 1954).

$\mathrm{X}$-ray diffraction (XRD) patterns were recorded using a Bruker D8 Advance diffractometer. We used a copper target $\mathrm{X}$-ray tube, operating at $40 \mathrm{kV}$ and $40 \mathrm{~mA}$. We collected measurements in the $3^{\circ}-70^{\circ} 2 \theta$ range, with a step size of $0.02^{\circ} 2 \theta$ and a scan rate of $4^{\circ} / \mathrm{min}$. From the XRD patterns, crystallinity index (CI) values of hydroxyapatite $\left[\mathrm{Ca}_{10}\left(\mathrm{PO}_{4}\right)_{6}(\mathrm{OH})_{2}\right]$ were determined following the methodology proposed by Landi et al. (2000). The crystallinity degree, corresponding to the fraction of

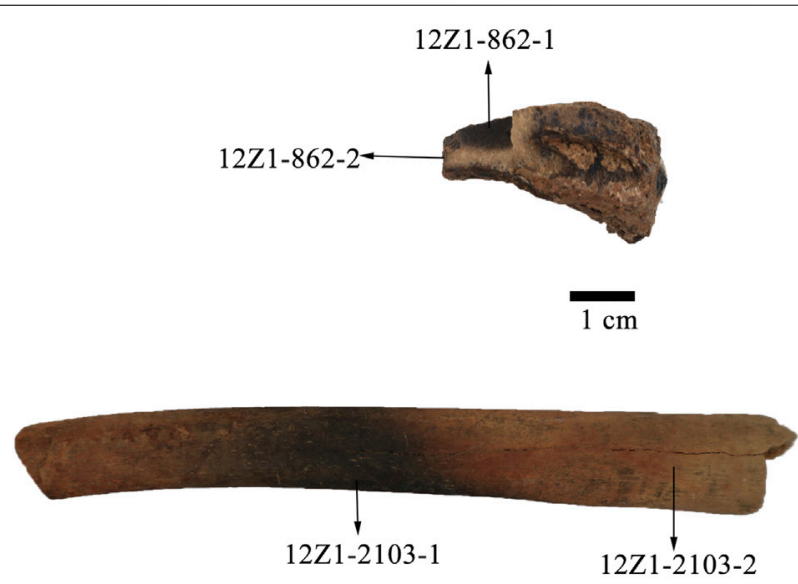

FIGURE 2 | Appearance of distinct colors in 12Z1-862 and 12Z1-2103.

TABLE 2 | Burned bone textures and criteria.

Texture code

1

2

3

4

\section{Description}

Unburned appearance without any burning fracture

Glass-like or bubbly char; curved, tiny fractures; clinker remains Little to no char, flat granular surface, little or extensive cracking Smoother surfaces, some warping 


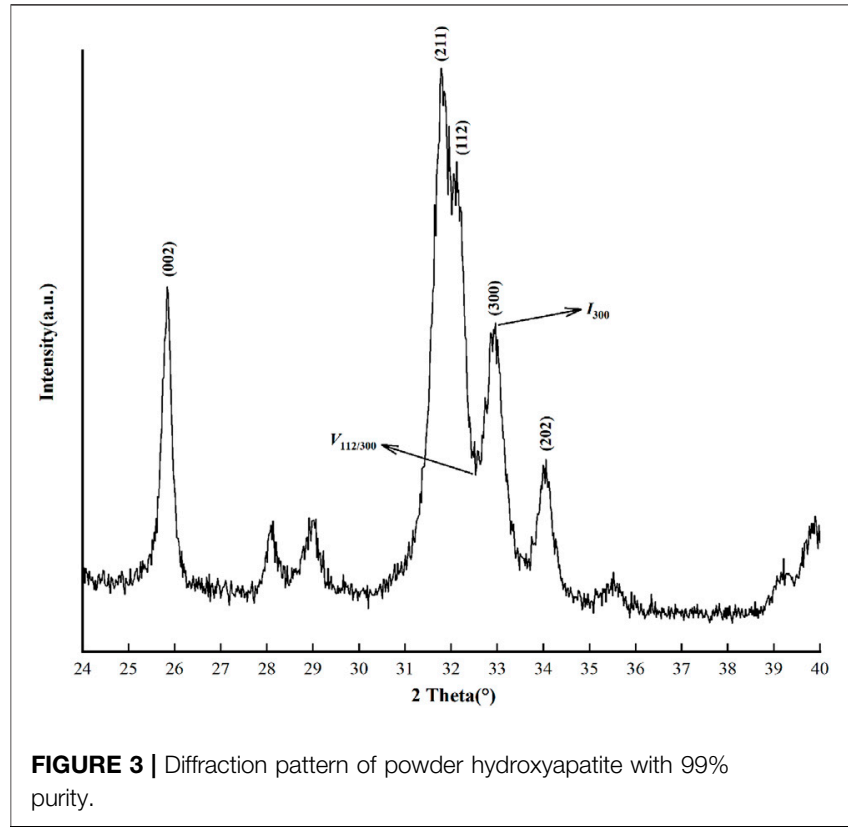

crystalline phase present in the examined volume, was evaluated using the relation

$$
X_{c} \approx 1-\left(\frac{V_{112 / 300}}{I_{300}}\right)
$$

where $I_{300}$ is the intensity of (300) reflection. Meanwhile, $V_{112 / 300}$ is the intensity of the hollow between (300) and (112) reflection, which completely disappears in non-crystalline samples (Figure 3).

Person et al. (1995), Stiner et al. (2001) pointed out that there was no correlation between increase in CI and age of fossil bone samples.

\section{RESULTS}

Table 3 shows results from macroscopic observation and XRD analysis. All samples were from Layer 4 except the Layer-5 sample 15Z1-0247. From the results we could see that the color codes ranged from 0 to 5 , and the powder colors described using the Munsell color chart showed more refined color descriptions. Texture codes ranged from 1 to 4 ; it seemed that cracks were not clear in some specimens, and we did not find any traces of clinker, meaning the bones were not burned green (Cain, 2005). The $\mathrm{CI}$ values ranged from 0.15 to 0.84 , mostly $>0.3$. In addition to hydroxyapatite, we also observed calcite and quartz in mineral composition, which implied diagenesis. We did not find traces of tooth marks.

\section{Bone Description}

As Figures 4, 5 show, we followed Nicholson (1993), Stiner et al. (1995) in choosing distinct colors of fossil bone to represent different burning intensities.
There was no fully calcined (i.e., completely white) bone among these samples, hence color code 6 was not used. However, in sample 15Z1-0247, the color of bone itself was hard to distinguish from the color in bones that showed a high intensity of burning (see Figure 5). The Munsell color code of powder in 15Z1-0247 was N 9/, making it the whitest sample. However, after reviewing the texture of the sample, we

TABLE 3 | Results from macroscopic observation and XRD analysis.

\begin{tabular}{|c|c|c|c|c|c|}
\hline ID & Color code & $\begin{array}{l}\text { Munsell color } \\
\text { code }\end{array}$ & Texture & Cl & Phase \\
\hline 15Z1-0247 & 0 & N9/White & 1 & 0.15 & HAP \\
\hline $12 Z 1-1873$ & 1 & $\begin{array}{l}\text { 10YR } 8 / 2 \\
\text { Very pale brown }\end{array}$ & 1 & 0.30 & $\begin{array}{l}\text { HAP } \\
\text { Calcite } \\
\text { Quartz }\end{array}$ \\
\hline 12Z1-1899 & 1 & $\begin{array}{l}\text { 10YR8/3 } \\
\text { Very pale brown }\end{array}$ & 1 & 0.25 & HAP \\
\hline $12 Z 1-1526$ & 1 & $\begin{array}{l}\text { 10YR8/3 } \\
\text { Very pale brown }\end{array}$ & 1 & 0.20 & $\begin{array}{l}\text { HAP } \\
\text { Calcite } \\
\text { Quartz }\end{array}$ \\
\hline 14Z1-0299 & 2 & $\begin{array}{l}\text { 10YR5/1 } \\
\text { Gray }\end{array}$ & 2 & 0.17 & HAP \\
\hline $14 Z 1-0273$ & 4 & N8/White & 3 & 0.44 & HAP \\
\hline $14 Z 1-0461$ & 5 & N8/White & 3 & 0.52 & HAP \\
\hline $14 Z 1-0143$ & 4 & $\begin{array}{l}\text { 10YR } 7 / 1 \\
\text { Light gray }\end{array}$ & 3 & 0.42 & HAP \\
\hline $14 Z 1-429$ & 3 & $\begin{array}{l}\text { 10YR5/2 } \\
\text { Grayish brown }\end{array}$ & 3 & 0.43 & HAP \\
\hline $14 Z 1-0163$ & 5 & $\begin{array}{l}\text { 10YR7/1 } \\
\text { Light gray }\end{array}$ & 3 & 0.39 & $\begin{array}{l}\text { HAP } \\
\text { Calcite } \\
\text { Quartz }\end{array}$ \\
\hline $14 Z 1-1665$ & 2 & $\begin{array}{l}\text { 10YR7/2 } \\
\text { Light gray }\end{array}$ & 3 & 0.28 & HAP \\
\hline $14 Z 1-1548$ & 3 & $\begin{array}{l}\text { 10YR4/1 } \\
\text { Dark gray }\end{array}$ & 4 & 0.39 & HAP \\
\hline $12 Z 1-1510$ & 4 & $\begin{array}{l}\text { 10YR5/2 } \\
\text { Grayish brown }\end{array}$ & 2 & 0.52 & HAP \\
\hline $12 Z 1-862-1$ & 3 & $\begin{array}{l}\text { 10YR5/1 } \\
\text { Gray }\end{array}$ & 2 & 0.2 & HAP \\
\hline $12 Z 1-862-2$ & 3 & $\begin{array}{l}\text { 10YR7/2 } \\
\text { Light gray }\end{array}$ & 2 & 0.38 & \\
\hline $12 Z 1-866$ & 3 & $\begin{array}{l}\text { 10YR4/1 } \\
\text { Dark gray }\end{array}$ & 2 & 0.16 & $\begin{array}{l}\text { HAP } \\
\text { Quartz }\end{array}$ \\
\hline $14 Z 1-0765$ & 5 & $\begin{array}{l}\text { 10YR8/1 } \\
\text { White }\end{array}$ & 3 & 0.84 & HAP \\
\hline $14 Z 1-0161$ & 4 & $\begin{array}{l}\text { 10YR5/1 } \\
\text { Gray }\end{array}$ & 4 & 0.43 & HAP \\
\hline 12Z1-2095 & 5 & N 8/White & 3 & 0.45 & $\begin{array}{l}\text { HAP } \\
\text { Calcite } \\
\text { Quartz }\end{array}$ \\
\hline $12 Z 1-2103-1$ & 1 & $\begin{array}{l}\text { Z23 10YR4/1 } \\
\text { Dark gray }\end{array}$ & 2 & 0.28 & $\begin{array}{l}\text { HAP } \\
\text { Calcite } \\
\text { Quartz }\end{array}$ \\
\hline 12Z1-2103-2 & 1 & $\begin{array}{l}\text { Z24 10YR8/2 } \\
\text { Very pale brown }\end{array}$ & 2 & 0.27 & $\begin{array}{l}\text { HAP } \\
\text { Quartz }\end{array}$ \\
\hline $14 Z 1-1571$ & 1 & $\begin{array}{l}\text { 10YR6/2 } \\
\text { Light brownish gray }\end{array}$ & 2 & 0.32 & $\begin{array}{l}\text { HAP } \\
\text { Quartz }\end{array}$ \\
\hline $12 Z 1-1729$ & 4 & 10YR4/1 & 3 & 0.28 & HAP \\
\hline $14 Z 1-1083$ & 3 & $\begin{array}{l}\text { Dark gray } \\
\text { 10YR5/1 } \\
\text { Gray }\end{array}$ & 3 & 0.33 & $\begin{array}{l}\text { Quartz } \\
\text { HAP }\end{array}$ \\
\hline $12 Z 1-0413$ & 3 & $\begin{array}{l}\text { 10YR5/2 } \\
\text { Grayish brown }\end{array}$ & 3 & 0.39 & $\begin{array}{l}\text { HAP } \\
\text { Calcite }\end{array}$ \\
\hline
\end{tabular}




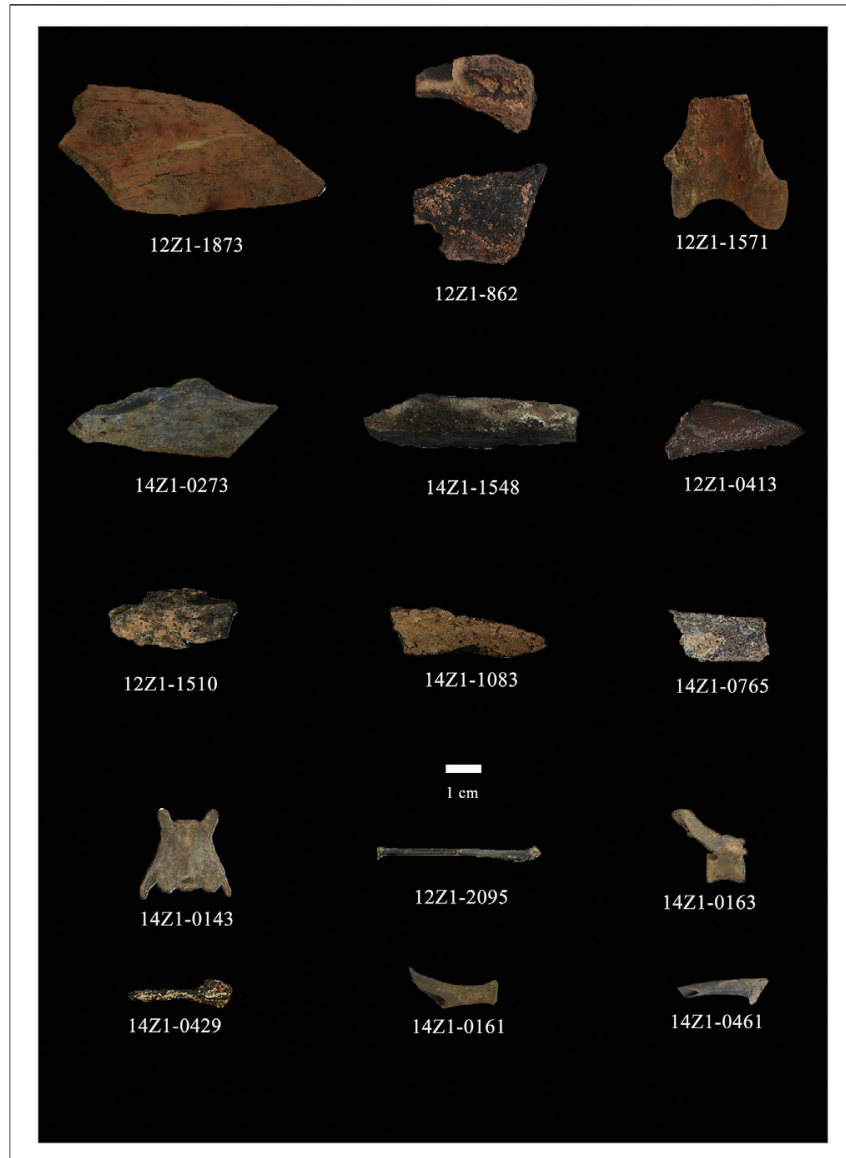

FIGURE 4 | Appearance of bone samples with $\mathrm{Cl}$ values $>0.3$, indicating the samples were heated to $600^{\circ} \mathrm{C}$ or above.

confirmed that there was no sign of burning; we finally settled on a color level of 0 rather than 6 .

We also observed a typical "sandwich" coloration in sample 12Z1-862 (see Figures 2, 4; Buikstra \& Swegle, 1989; Barkai et al., 2017). The coloration in intracortical tissue was different with respect to that observed on the outer side, as occurs when bone elements are subjected to partial heat or incomplete combustion while maintaining their fat content (Cerdá et al., 2005). We collected inner and outer powder samples for XRD analysis. In sample 12Z12103 (see Figure 5), two areas of cortical bone were observed to differ greatly in color, the middle area appearing black while the other areas were reddish brown. We also collected powder samples from these two different color regions for XRD analysis.

\section{XRD Analysis}

The XRD pattern of all samples are shown in Figures 6, 7 (all raw data are listed in the supplementary materials).

The XRD mineral study indicated similarity among the samples, with hydroxyapatite present in all samples and calcite $\left(\mathrm{CaCO}_{3}\right)$ in some, as well as quartz $\left(\mathrm{SiO}_{2}\right.$; see Table 3). These mineralogical compositions are far different from that presented

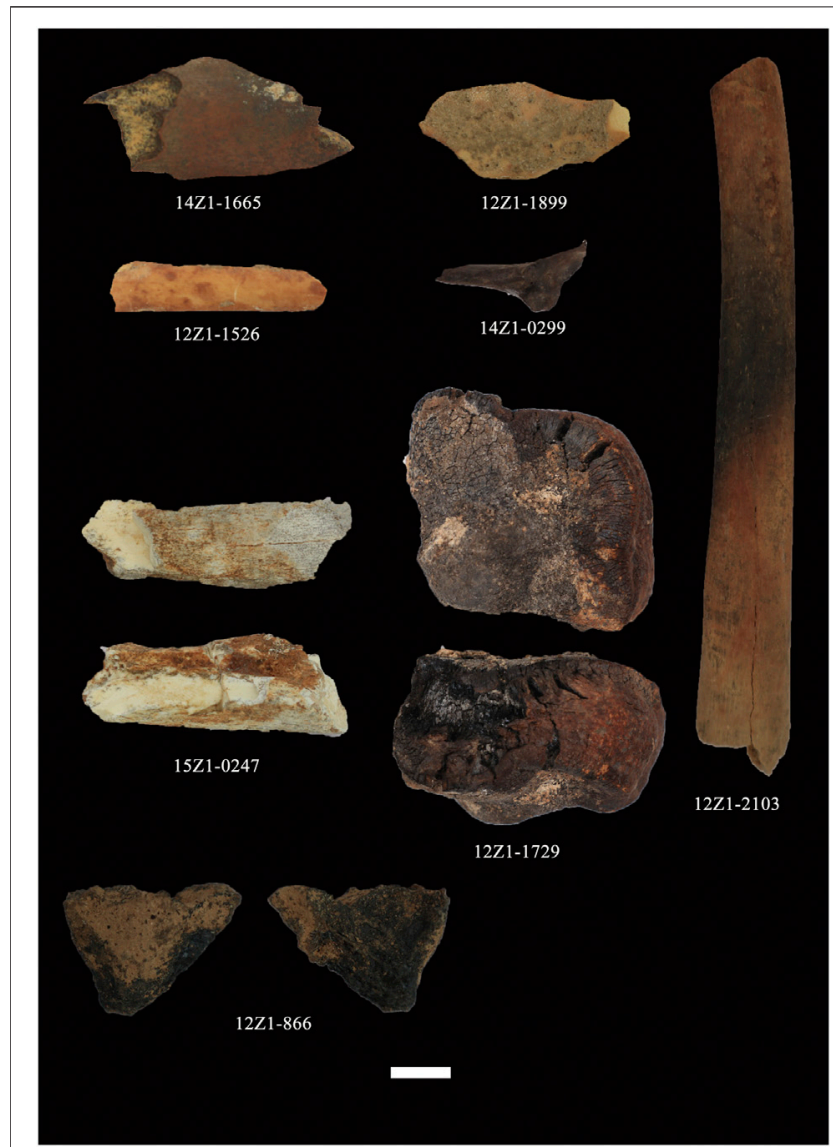

FIGURE 5 | Appearance of bone samples with $\mathrm{Cl}$ values <0.3, indicating the samples were probably heated to temperatures lower than $600^{\circ} \mathrm{C}$.

by unaltered, fresh bone (Figure 8). With respect to crystallinity measurements, the CI ranged from 0.15 to 0.84 (Table 3).

\section{DISCUSSION}

The results we obtained through macroscopic observations and XRD analysis show undoubtable proof that the fossil bones from Layer 4 were burned.

Darker colorations in fossil bones usually indicate they have been subjected to thermal events. The coloration of bone is thus a commonly used characteristic to identify past events of burning. Several experimental studies have identified heating temperature from bone color (Shipman et al., 1984; Nicholson, 1993; Stiner et al., 1995). But in our study, we can see that the range of color does not accurately represent degrees of heating between fossil bones. In our previous research, we found that the $\mathrm{CI}$ values for all pretreated bones heated above $600^{\circ} \mathrm{C}$ were above 0.3 (Table 4; Huang and Zhang, 2021). And bones burned at high intensity can be clearly recognized from other archaeological bones by XRD patterns and CI values (Lebon et al., 2010). This means a total of 15 bone samples, which CI values above 0.3 , were likely burned at $600^{\circ} \mathrm{C}$ or even higher (Table 3; Figure 4). 


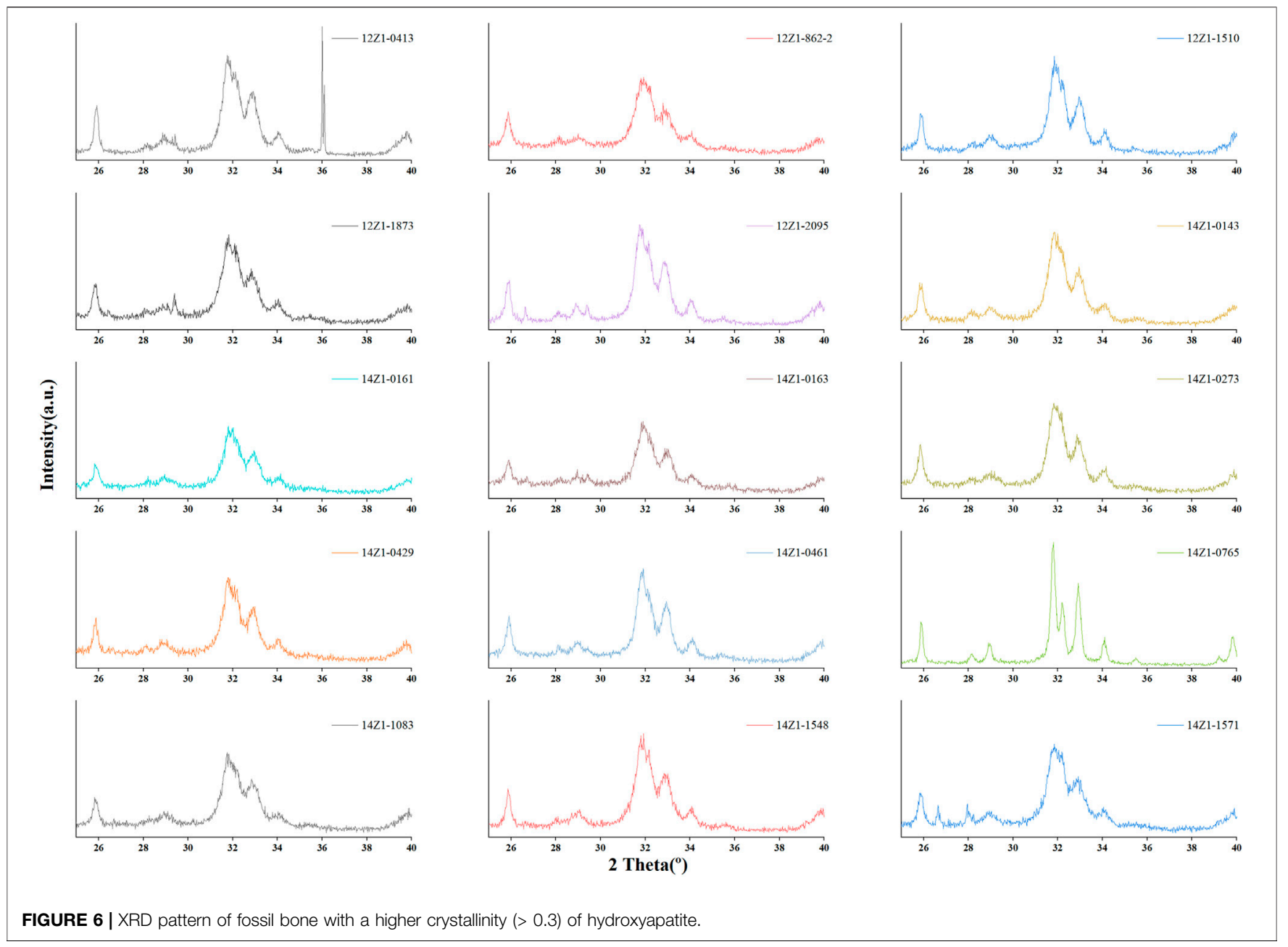

The color of bone can be used to distinguish the intensity of burning in experimental conditions (Shipman et al., 1984). In archaeological bone, color is not a reliable criterion. There are multiple distractions that can affect judgment, such as oxide staining (Shahack-Gross et al., 1997) or taphonomic effects (Behrensmeyer, 1978). Sample 15Z1-0247 from Layer 5 is a fossil bone without any macroscopic characteristic of burning, even though it matched a Munsell color code similar to 14Z10273 and 14Z1-0461, which have obvious burned textures (Figure 4). The whitish coloration of sample 15Z1-0247 seems rather to indicate a diagenetic effect because it also has a low CI value and presents precipitation of manganese oxides. As a check for burning intensity, examining the texture of bone is indispensable (Cain, 2005).

In sample 12Z1-866, the observed coloration and texture shows a similar result for a high burning degree. However, the CI value for the sample is 0.16 , meaning a very low burning intensity (the CI value of $15 Z 1-0247$ is 0.15 ); moreover, the peaks of hydroxyapatite are not clear from the XRD pattern (Figure 7). We confirmed that sample 12Z1-866 experienced only very low levels of combustion through XRD analysis, showing its importance as a method of determining combustion events even if color and texture appear to suggest burning.
The "sandwich" coloration was detected in sample 12Z1862 as we took two powder samples from different color areas on 12Z1-862 (see Figure 2). The Munsell color of the powder shows that 12Z1-862-1 (taken from the outer side) is gray while 12Z1-862-2 (taken from the middle) is light gray. This means 12Z1-862-2 shows a higher intensity of burning, as supported by the corresponding CI values (see Table 3 ). Similarly, we examined the CI values of two parts of different color from sample 12Z1-2103 (Figure 2). Despite the obvious color differences between the two regions, their CI values are very close, both lower than in charry or calcine bone. This means the whole bone was subjected to a low degree of combustion. Considering that it is part of a rib, this bone with patches of black alteration, burned at low intensity, may be robust evidence of hominin maintenance and use of fire at Layer 4 (Zhang et al., 2020).

The mineral phase of bones undergoes significant changes while burning. The original mineral in bone is a carbonate-hydroapatite, not hydroxyapatite (Elliott, 2002; Monge et al., 2014; Schmahl et al., 2017). With increased temperature, the carbonate will leave the bone and, from about 500 to $600^{\circ} \mathrm{C}$, the bone mineral progressively reacts to form hydroxyapatite with increasing purity and crystallite size as temperature continues 


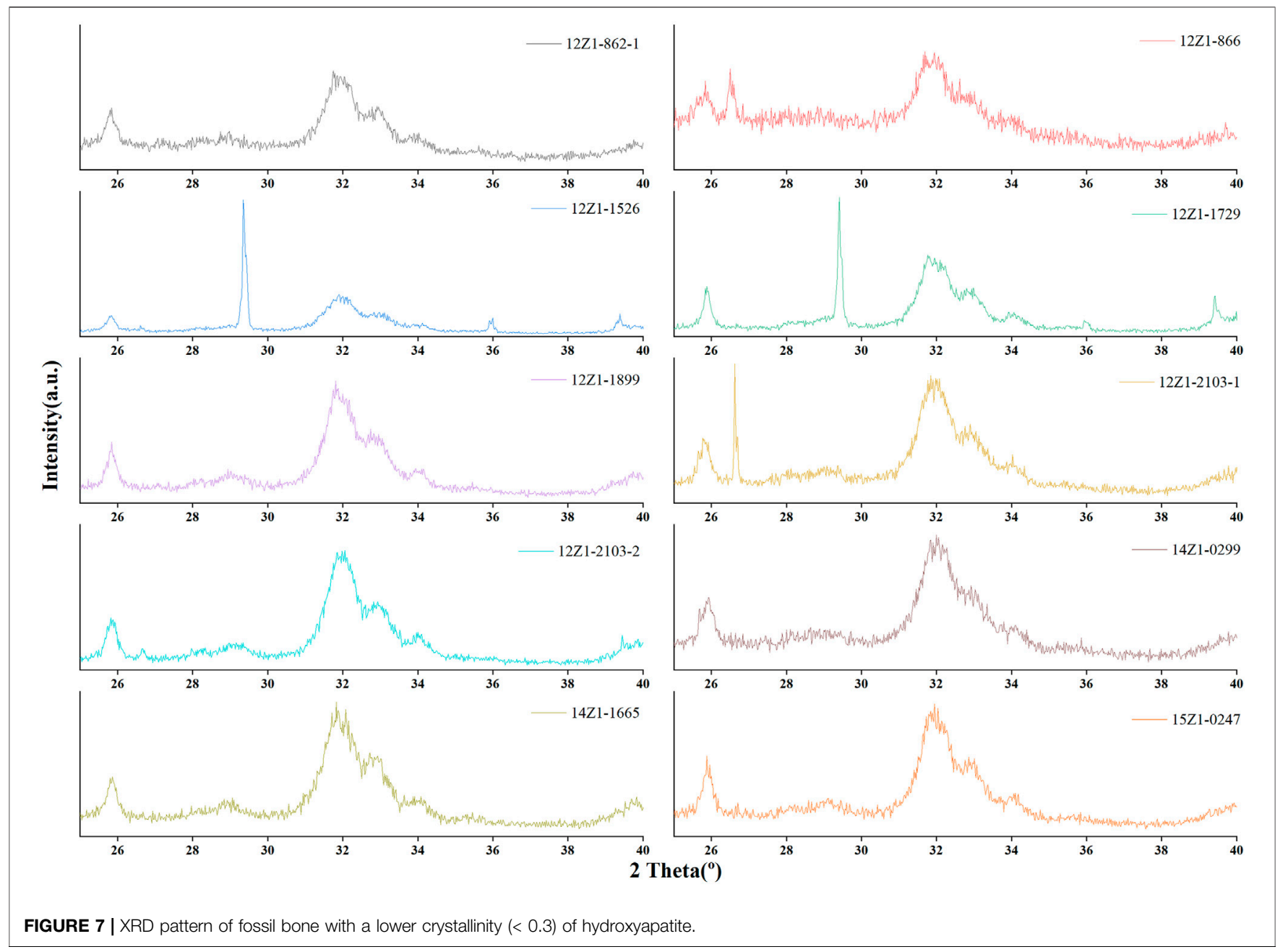

to increase (Shipman et al., 1984; Rogers and Daniels, 2002; Schmahl et al., 2017; Mckinnon et al., 2020).

The XRD pattern for 12Z1-1526, as well as its low CI values of hydroxyapatite (Figure 7) and corresponding to its grade of color and texture, shows that its main mineral phase is calcite rather than hydroxyapatite. We can also see that in a bone burned at high intensity, such as 14Z1-0765, the peaks of calcite are absent from the XRD pattern while the CI value of hydroxyapatite is high and its peaks are sharper (Figure 6).

Meanwhile, quartz is found in some fossil bones through XRD analysis. This quartz could be related to diagenetic processes and secondary calcite (Monge et al., 2014).

The presence of whitlockite $\left[\mathrm{Ca}_{9}\left(\mathrm{Mg}, \mathrm{Fe}^{2+}\right)\left(\mathrm{PO}_{4}\right)_{6}\left(\mathrm{PO}_{3} \mathrm{OH}\right)\right]$ also shows thermal events (Monge et al., 2014), but whitlockite is absent from our samples. This may be due to the small number of burned bone we sampled, especially as they show evidence of burning at high intensity. In our previously study, we confirmed that calcium phosphate tribasic $\left[\mathrm{Ca}_{3}\left(\mathrm{PO}_{4}\right)_{2}\right]$ presented in some experimental calcine bones (Huang and Zhang, 2021). Greiner et al. (2019) also reported the presence of $\mathrm{CaNaPO}_{4}$ in bones with high degrees of burning. Those phosphatic phases may show decomposition of hydroxyapatite at elevated temperatures.

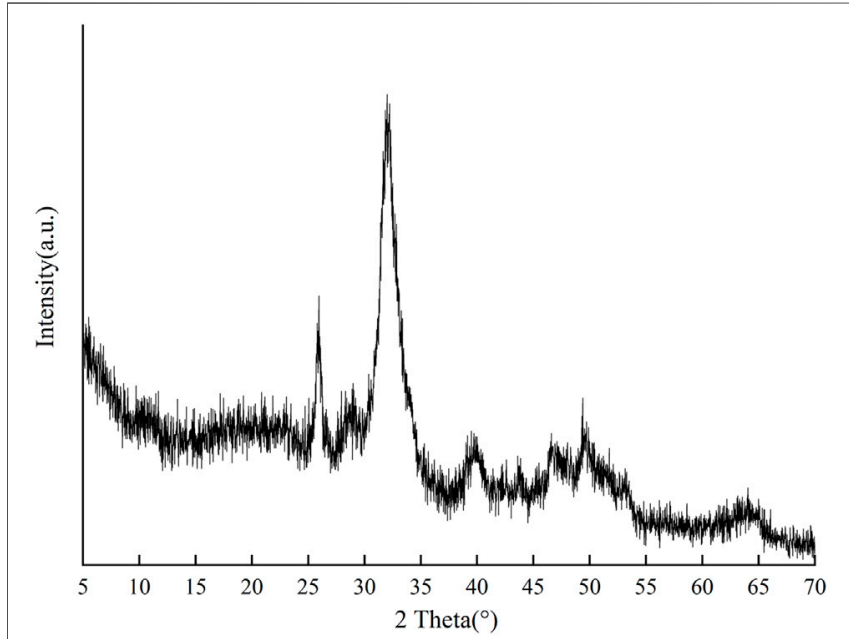

FIGURE 8 | XRD pattern of fresh bone.

In earlier studies at Zhoukoudian Locality 1, the results of elemental carbon analysis suggested that the burned items were probably burned in situ (Shen, 2004). Spatial analysis of 
TABLE 4 | Crystallinity index values of three pretreated bones (duration: $120 \mathrm{~min}$ ).

\begin{tabular}{lccc} 
Temperature $\left({ }^{\circ} \mathbf{C}\right)$ & Fleshed bone & Defleshed bone & Degreased bone \\
\hline 550 & 0.188 & 0.120 & 0.295 \\
600 & 0.375 & 0.373 & 0.408 \\
650 & 0.884 & 0.656 & 0.506 \\
700 & 0.959 & 0.928 & 0.825 \\
750 & 0.936 & 0.914 & 0.778 \\
800 & 0.951 & 0.957 & 0.913 \\
\hline
\end{tabular}

Zhoukoudian Locality 1 showed that stone tools and the burning of fresh bone associated with Homo erectus pekinensis supported a model of transient hominid scavenging aided by fire (Boaz et al., 2004). Analyses of sediments from the locality also provided evidence of in situ use of fire by Homo erectus pekinensis (Zhong et al., 2013; Zhang et al., 2014). These findings supplied new technical evidence of the use of fire by Homo erectus pekinensis. Along with re-excavation, new data on phenomena of in situ fire use have been discovered from Layer 4 (Gao et al., 2017). Based on these findings, our study recognizes bones from Layer 4 that were heated to above $600^{\circ} \mathrm{C}$, likely resulting from hominids' use of fire. Gowlett et al. (2017) argued that temperature is not a reliable parameter in recognizing grass fires and human-controlled fires: both range through $200-800^{\circ} \mathrm{C}$. However, grass fires would not last long. During the formation of Layer 4, parts of the cave roof remained at Zhoukoudian Locality 1 (Gao et al., 2017), meaning the environment probably did not support many weeds, let alone shrubs. Therefore, the available evidence does not support the existence of large, prolonged wildfires in Layer 4 . The high intensity of burning in fossil bones is most likely the result of hominins using fire.

\section{CONCLUSION}

Macroscopic observation is regularly used to identify burned bone from archaeological sites, but it is not reliable in some cases because of taphonomic or diagenetic effects. Therefore, technological method such as XRD analysis (an efficient method for identifying burned bones) is necessary. It can be used to calibrate our recognition of burned bones and find degrees of burning in bones. Future studies can focus more on phosphate formation and transformation of hydroxyapatite during burning and the process of diagenesis.

It has been demonstrated that the bones excavated from Zhoukoudian Locality 1 Layer 4 were heated to different

\section{REFERENCES}

Baby, R. S. (1954), Hopewell Cremation Practices. Papers in Archaeology, 1. Columbus, Ohio: Ohio Historical Society, 1-7.

Barkai, R., Rosell, J., Blasco, R., and Gopher, A. (2017). Fire for a Reason. Curr. Anthropol. 58 (S16), S314-S328. doi:10.1086/691211

Behrensmeyer, A. K. (1978). Taphonomic and Ecologic Information from Bone Weathering. Paleobiology 4 (2), 150-162. doi:10.1017/S0094837300005820

Bennett, J. L. (1999). Thermal Alteration of Buried Bone. J. Archaeological Sci. 26 (26), 1-8. doi:10.1006/jasc.1998.0283 degrees in this study. Evidence of thermal events is reflected in their colorations, textures, mineral phases, and CI values. Even though phosphatic phases are absent, the presence of hydroxyapatite and high CI values are enough to suggest that the bones had been burned, most of them to $600^{\circ} \mathrm{C}$. These high intensities of burning are most likely the result of hominins' use of fire. Further research should be centered on burned items from the lower layers in order to obtain more evidence of hominin maintenance and use of fire.

\section{DATA AVAILABILITY STATEMENT}

The original contributions presented in the study are included in the article/Supplementary Material, further inquiries can be directed to the corresponding author.

\section{AUTHOR CONTRIBUTIONS}

XG designed the study. $\mathrm{CH}$ and JL conducted the study. $\mathrm{CH}$ wrote the initial version of the manuscript. $\mathrm{XG}$ and $\mathrm{CH}$ reviewed and edited the final version of manuscript.

\section{FUNDING}

This work was funded by the grants from the National Natural Science Foundation of China (41672023) and the Strategic Priority Research Program of the Chinese Academy of Science (Grant No. XDB26000000).

\section{ACKNOWLEDGMENTS}

We would like to thank our colleagues and others for their participation in the field work at Zhoukoudian from 2012 to 2015. We like to thank two Reviewers for their pertinent suggestions. We appreciate Editors' warm work earnestly.

\section{SUPPLEMENTARY MATERIAL}

The Supplementary Material for this article can be found online at: https://www.frontiersin.org/articles/10.3389/feart.2021.811319/ full\#supplementary-material

Binford, L. R., Ho, C. K., Aigner, J. S., Alimen, M.-H., Borrero, L. A., Chung, T., et al. (1985). Taphonomy at a Distance: Zhoukoudian, "The Cave Home of Beijing Man"? [and Comments and Reply]. Curr. Anthropol. 26 (4), 413-442. doi:10.1086/203303

Binford, L. R., Stone, N. M., Aigner, J. S., Behrensmeyer, A. K., Haynes, G., Olsen, J. W., et al. (1986). Zhoukoudian: A Closer Look [and Comments and Reply]. Curr. Anthropol. 27 (5), 453-475. doi:10.1086/203469

Black, D. (1931). Evidences of the Use of Fire by Sinanthropus. Bull. Geol. Soc. China 11 (2), 107-108.

Boaz, N. T., Ciochon, R. L., Xu, Q., and Liu, J. (2004). Mapping and Taphonomic Analysis of the Homo Erectus Loci at Locality 1 Zhoukoudian, China. J. Hum. Evol. 46 (5), 519-549. doi:10.1016/j.jhevol.2004.01.007 
Brain, C. K., and Sillent, A. (1988). Evidence from the Swartkrans Cave for the Earliest Use of Fire. Nature 336 (6198), 464-466. doi:10.1038/336464a0

Brain, C. K. (1993). "The Occurrence of Burnt Bones at Swartkrans and Their Implications for the Control of Fire by Early Hominids," in Swartkrans: A Cave's Chronicle of Early Man. Editor C. K. Brain (Pretoria: Transvaal Museum), 229-242. (Reprinted).

Buikstra, J. E., and Swegle, M. (1989). "Bone Modification due to Burning: Experimental Evidence," in Bone Modification. Editors R. Bonnichsen and M. H. Sorg (Maine: CENTER FOR THE STUDY THE FIRST AMERICANS Institute for Quaternary Studies Press), 247-258.

Cain, C. R. (2005). Using Burned Animal Bone to Look at Middle Stone Age Occupation and Behavior. J. Archaeological Sci. 32 (6), 873-884. doi:10.1016/ j.jas.2005.01.005

Cerdá, Manuel. Polo., García-Prósper, Elisa., and Sanchis Serra, Alfred. (2005). Estudio bioarqueológico de las cremaciones del monumento funerario romano del "solar de la morería" de Sagunto. Arse: Boletín Anual Del. Centro Arqueológico Saguntino 39, 229-268.

Elliott, J. C. (2002). Calcium Phosphate Biominerals. Rev. Mineralogy Geochem. 48 (1), 427-453. doi:10.2138/rmg.2002.48.11

Etok, S. E., Valsami-Jones, E., Wess, T. J., Hiller, J. C., Maxwell, C. A., Rogers, K. D., et al. (2007). Structural and Chemical Changes of Thermally Treated Bone Apatite. J. Mater. Sci. 42 (23), 9807-9816. doi:10.1007/s10853-007-1993-z

Gao, X., Cote, P., Blais, J.-P., Dong, W., Tong, H., Derobert, X., et al. (2016). Geophysical Investigations Identify Hidden Deposits with Great Potential for Discovering Peking Man Fossils at Zhoukoudian, China. Quat. Int. 400, 30-35. doi:10.1016/j.quaint.2015.05.050

Gao, X., Zhang, S., Zhang, Y., and Chen, F. (2017). Evidence of Hominin Use and Maintenance of Fire at Zhoukoudian. Curr. Anthropol. 58 (S16), S267-S277. doi:10.1086/692501

Goldberg, P., Weiner, S., Bar-Yosef, O., Xu, Q., and Liu, J. (2001). Site Formation Processes at Zhoukoudian, China. J. Hum. Evol. 41 (5), 483-530. doi:10.1006/ jhev.2001.0498

Gowlett, J. A. J., Brink, J. S., Caris, A., Hoare, S., and Rucina, S. M. (2017). Evidence of Burning from Bushfires in Southern and East Africa and its Relevance to Hominin Evolution. Curr. Anthropol. 58 (S16), S206-S216. doi:10.1086/692249

Greiner, M., Rodríguez-Navarro, A., Heinig, M. F., Mayer, K., Kocsis, B., Göhring, A., et al. (2019). Bone Incineration: An Experimental Study on mineral Structure, Colour and Crystalline State. J. Archaeological Sci. Rep. 25, 507-518. doi:10.1016/j.jasrep.2019.05.009

Guo, S., Liu, S. S., Sun, S. F., Zhang, F., Zhou, S. H., Hao, X. H., et al. (1991). Fission Track Dating of 4th Layer of the Peking Man Site. Acta Anthropologica Sinica 10 (01). [In Chinese]. doi:10.16359/j.cnki.cn11-1963/q.1991.01.011

Herrmann, B. (1977). On Histological Investigations of Cremated Human Remains. J. Hum. Evol. 6 (2), 101-103. doi:10.1016/S0047-2484(77)80112-7

Hlubik, S., Berna, F., Feibel, C., Braun, D., and Harris, J. W. K. (2017). Researching the Nature of Fire at 1.5 Mya on the Site of FxJj20 AB, Koobi Fora, Kenya, Using High-Resolution Spatial Analysis and FTIR Spectrometry. Curr. Anthropol. 58 (S16), S243-S257. doi:10.1086/692530

Holden, J. L., Clement, J. G., and Phakey, P. P. (1995). Age and Temperature Related Changes to the Ultrastructure and Composition of Human Bone Mineral. J. Bone Miner Res. 10 (9), 1400-1409. doi:10.1002/jbmr.5650100918

Landi, E., Tampieri, A., Celotti, G., and Sprio, S. (2000). Densification Behaviour and Mechanisms of Synthetic Hydroxyapatites. J. Eur. Ceram. Soc. 20 (14-15), 2377-2387. doi:10.1088/0143-0807/27/4/007

Huang, C., and Zhang, S. Q. (2021). Preliminary Application of the X-Rays Diffraction Technique in Experimental Study of Burnt Bones. Acta Anthropologica Sinica (03), 513-525. [In Chinese]. doi:10.16359/j.1000-3193/ aas. 2021.0042

Lebon, M., Reiche, I., Bahain, J.-J., Chadefaux, C., Moigne, A.-M., Fröhlich, F., et al. (2010). New Parameters for the Characterization of Diagenetic Alterations and Heat-Induced Changes of Fossil Bone mineral Using Fourier Transform Infrared Spectrometry. J. Archaeological Sci. 37 (9), 2265-2276. doi:10.1016/ j.jas.2010.03.024

Lebon, M., Reiche, I., Fröhlich, F., Bahain, J.-J., and Falguères, C. (2008). Characterization of Archaeological Burnt Bones: Contribution of a New Analytical Protocol Based on Derivative FTIR Spectroscopy and Curve Fitting of the $v 1 \vee 3$ PO4 Domain. Anal. Bioanal. Chem. 392 (7-8), 1479-1488. doi:10.1007/s00216-008-2469-y
Ludwig, K. R., and Renne, P. R. (2000). Geochronology on the Paleoanthropological Time Scale. Evol. Anthropol. 9 (2), 101-110. doi:10.1002/(sici)1520-6505(2000)9:2<101:aid-evan4>3.0.co;2-w

Mckinnon, M., Henneberg, M., Simpson, E., and Higgins, D. (2020). A Comparison of crystal Structure in Fresh, Burned and Archaic Bone Implications for Forensic Sampling. Forensic Sci. Int. 313, 110328. doi:10.1016/j.forsciint.2020.110328

Monge, G., Carretero, M. I., Pozo, M., and Barroso, C. (2014). Mineralogical changes in fossil bone from Cueva del Angel, Spain: archaeological implications and occurrence of whitlockite. J. Archaeological Sci. 46, 6-15. doi:10.1016/ j.jas.2014.02.033

Munsell Color Company (1954). Munsell Soil Color Chart. Baltimore, MD: Munsell Color.

Nicholson, R. A. (1993). A Morphological Investigation of Burnt Animal Bone and an Evaluation of its Utility in Archaeology. J. Archaeological Sci. 20 (4), 411-428. doi:10.1006/jasc.1993.1025

Oakley, K. P. (1961). On Man's Use of Fire, with Comments on Tool-Making and Hunting. Social Life Early Man, 176-193. doi:10.4324/9781315017761

Oakley, K. (1956). The Earliest Fire-Makers. Antiquity 30 (118), 102-107. doi:10.1017/S0003598X00028313

Pei, J. X. (1985). Thermoluminescence Dating for Cave Deposits of Zhoukoudian and Other Cave Sites. In Multidisciplinary Study of the Peking Man Site at Zhoukoudian. R. K. Wu, M. E. Ren, X. M. Zhu, Z. G. Yang, C. G. Hu, Z. C. Kong, et al. eds. Pp. 256-260. Beijing: Science Press. [In Chinese.]

Pei, W. C. (1934). A Preliminary Report on the Late Palaeolithic Cave of Choukoutien. Bull. Geol. Soc. China 13, 327-358. doi:10.1111/j.17556724.1934.mp13001020.x

Person, A., Bocherens, H., Saliège, J.-F., Paris, F., Zeitoun, V., and Gérard, M. (1995). Early Diagenetic Evolution of Bone Phosphate: An X-ray Diffractometry Analysis. J. Archaeological Sci. 22 (2), 211-221. doi:10.1006/ jasc. 1995.0023

Reidsma, F. H., van Hoesel, A., van Os, B. J. H., Megens, L., and Braadbaart, F. (2016). Charred Bone: Physical and Chemical Changes during Laboratory Simulated Heating under Reducing Conditions and its Relevance for the Study of Fire Use in Archaeology. J. Archaeological Sci. Rep. 10, 282-292. doi:10.1016/ j.jasrep.2016.10.001

Richards, D. A., and Dorale, J. A. (2003). 10. Uranium-Series Chronology and Environmental Applications of Speleothems. Rev. Mineralogy Geochem. 52 (1), 407-460. doi:10.2113/0520407

Roebroeks, W., and Villa, P. (2011). On the Earliest Evidence for Habitual Use of Fire in Europe. Proc. Natl. Acad. Sci. 108 (13), 5209-5214. doi:10.1073/ pnas. 1018116108

Rogers, K. D., and Daniels, P. (2002). An X-ray Diffraction Study of the Effects of Heat Treatment on Bone mineral Microstructure. Biomaterials 23 (12), 2577-2585. doi:10.1016/s0142-9612(01)00395-7

Schiegl, S., Goldberg, P., Bar-Yosef, O., and Weiner, S. (1996). Ash Deposits in Hayonim and Kebara Caves, Israel: Macroscopic, Microscopic and Mineralogical Observations, and Their Archaeological Implications. J. Archaeological Sci. 23 (5), 763-781. doi:10.1006/jasc.1996.0071

Schmahl, W. W., Kocsis, B., Toncala, A., Wycisk, D., and Grupe, G. (2017). "The Crystalline State of Archaeological Bone Material," in Across the Alps in Prehistory. Editor G. G. E. Al (Springer International Publishing), 75-104. (Reprinted). doi:10.1007/978-3-319-41550-5_4

Shahack-Gross, R., Bar-Yosef, O., and Weiner, S. (1997). Black-Coloured Bones in Hayonim Cave, Israel: Differentiating between Burning and Oxide Staining. J. Archaeological Sci. 24 (5), 439-446. doi:10.1006/jasc.1996.0128

Shen, C. (2004). Concentrations of ?elemental Carbon? in Samples from the Peking Man Site at Zhoukoudian and the Possibility of Their Application in the Development of Evidence for the Use of Fire by Humans. Chin. Sci Bull 49 (6), 612. doi:10.1360/03wd0209

Shen, G., Gao, X., Gao, B., and Granger, D. E. (2009). Age of Zhoukoudian Homo Erectus Determined with $26 \mathrm{Al} / 10 \mathrm{Be}$ Burial Dating. Nature 458 (7235), 198-200. doi:10.1038/nature07741

Shen, G., Ku, T.-L., Cheng, H., Edwards, R. L., Yuan, Z., and Wang, Q. (2001). High-precision U-Series Dating of Locality 1 at Zhoukoudian, china. J. Hum. Evol. 41 (6), 679-688. doi:10.1006/jhev.2001.0516

Shipman, P., Foster, G., and Schoeninger, M. (1984). Burnt Bones and Teeth: an Experimental Study of Color, Morphology, crystal Structure and 
Shrinkage. J. Archaeological Sci. 4 (11), 307-325. doi:10.1016/03054403(84)90013-X

Sillen, A., and Hoering, T. (1993). "Chemical Characterization of Burnt Bones from Swartkrans," in Swartkrans: A Cave's Chronicle of Early Man. Editor C. K. Brain (Pretoria: Transvaal Museum), 243-249. (Reprinted).

Squires, K. E., Thompson, T. J. U., Islam, M., and Chamberlain, A. (2011). The Application of Histomorphometry and Fourier Transform Infrared Spectroscopy to the Analysis of Early Anglo-Saxon Burned Bone. J. Archaeological Sci. 38 (9), 2399-2409. doi:10.1016/j.jas.2011.04.025

Stiner, M. C., Kuhn, S. L., Surovell, T. A., Goldberg, P., Meignen, L., Weiner, S., et al. (2001). Bone Preservation in Hayonim Cave (Israel): a Macroscopic and Mineralogical Study. J. Archaeological Sci. 28 (6), 643-659. doi:10.1006/ jasc.2000.0634

Stiner, M. C., Kuhn, S. L., Weiner, S., and Bar-Yosef, O. (1995). Differential Burning, Recrystallization, and Fragmentation of Archaeological Bone. J. Archaeological Sci. 22 (2), 223-237. doi:10.1006/jasc.1995.0024

Taylor, R. E., Hare, P. E., and White, T. D. (1995). Geochemical Criteria for thermal Alteration of Bone. J. Archaeological Sci. 22 (1), 115-119. doi:10.1016/S03054403(95)80169-3

Théry-Parisot, I. (2002). Fuel Management (Bone and Wood) During the Lower Aurignacian in the Pataud Rock Shelter (Lower Palaeolithic, Les Eyzies de Tayac, Dordogne, France). Contribution of Experimentation. J. Archaeological Sci. 29 (12), 1415-1421. doi:10.1006/jasc.2001.0781

Thompson, T. J. U. (2004). Recent Advances in the Study of Burned Bone and Their Implications for Forensic Anthropology. Forensic Sci. Int. 146, S203-S205. doi:10.1016/j.forsciint.2004.09.063

van Hoesel, A., Reidsma, F. H., van Os, B. J. H., Megens, L., and Braadbaart, F. (2019). Combusted Bone: Physical and Chemical Changes of Bone during Laboratory Simulated Heating under Oxidising Conditions and Their Relevance for the Study of Ancient Fire Use. J. Archaeological Sci. Rep. 28, 102033. doi:10.1016/j.jasrep.2019.102033

Weiner, S., Goldberg, P., and Bar-Yosef, O. (1993). Bone Preservation in Kebara Cave, israel Using On-Site Fourier Transform Infrared Spectrometry. J. Archaeological Sci. 20 (6), 613-627. doi:10.1006/jasc.1993.1037

Weiner, S., Xu, Q., Goldberg, P., Liu, J., and Bar-Yosef, O. (1998). Evidence for the Use of Fire at Zhoukoudian, China. Science 281 (5374), 251-253. doi:10.1126/ science.281.5374.251

Wells, C. (1960). A Study of Cremation. Antiquity 34 (133), 29-37. doi:10.1017/ s0003598x00035146
Wrangham, R., and Conklin-Brittain, N. (2003). 'Cooking as a Biological Trait'. Comp. Biochem. Physiol. A: Mol. Integr. Physiol. 136 (1), 35-46. doi:10.1016/ S1095-6433(03)00020-5

Wu, X. (1999). Investigating the Possible Use of Fire at Zhoukoudian, China. Science 283, 299. doi:10.1126/science.283.5400.299a

Yravedra, J., and Uzquiano, P. (2013). Burnt Bone Assemblages from El Esquilleu Cave (Cantabria, Northern Spain): Deliberate Use for Fuel or Systematic Disposal of Organic Waste?. Quat. Sci. Rev. 68, 175-190. doi:10.1016/ j.quascirev.2013.01.019

Zhang, S., Zhang, Y., Pei, S., and Gao, X. (2020). Human Exploitation of Carnivores in Pleistocene China: A Case Study of the Faunal Remains from Shuidonggou Locality 7. Sci. China Earth Sci. 63 (1), 132-144. doi:10.1007/s11430-019-9389-9

Zhang, Y., Guo, Z., Deng, C., Zhang, S., Wu, H., Zhang, C., et al. (2014). The Use of Fire at Zhoukoudian: Evidence from Magnetic Susceptibility and Color Measurements. Chin. Sci. Bull. 59 (10), 1013-1020. doi:10.1007/s11434-0130111-7

Zhong, M., Shi, C., Gao, X., Wu, X., Chen, F., Zhang, S., et al. (2013). On the Possible Use of Fire by Homo Erectus at Zhoukoudian, China. Chin. Sci. Bull. 59 (3), 335-343. doi:10.1007/s11434-013-0061-0

Conflict of Interest: The authors declare that the research was conducted in the absence of any commercial or financial relationships that could be construed as a potential conflict of interest.

The handling Editor declared a past co-authorship with one of the authors XG.

Publisher's Note: All claims expressed in this article are solely those of the authors and do not necessarily represent those of their affiliated organizations, or those of the publisher, the editors and the reviewers. Any product that may be evaluated in this article, or claim that may be made by its manufacturer, is not guaranteed or endorsed by the publisher.

Copyright (c) 2022 Huang, Li and Gao. This is an open-access article distributed under the terms of the Creative Commons Attribution License (CC BY). The use, distribution or reproduction in other forums is permitted, provided the original author(s) and the copyright owner(s) are credited and that the original publication in this journal is cited, in accordance with accepted academic practice. No use, distribution or reproduction is permitted which does not comply with these terms. 